УДК 666.97:691.322

\author{
В.В. ТКАЧУК, \\ Луцький національний технічний університет, \\ О.А. ПРЯДКО \\ Національний університет біоресурсів і природокористування Украӥни
}

\title{
ЕКОЛОГІЧНІ ВЛАСТИВОСТІ БУДІВЕЛЬНИХ МАТЕРІАЛІВ
}

\author{
В.В. ТКАЧУК, \\ Луикий национальный технический университет,
}

О.А. ПРЯДКО

Наџиональний университет биоресурсов и природопользования Украиньл

\section{ЭКОЛОГИЧЕСКИЕ СВОЙСТВА СТРОИТЕЛЬНЫХ МАТЕРИАЛОВ}

\author{
V.V. TKACHUK, \\ Lutsk National Technical University, \\ O.A. PRIADKO
}

National university of life and environmental sciences of Ukraine

\section{ECOLOGICAL PROPERTIES OF BUILDING MATERIALS}

\section{https://doi.org/10.36910/6775-2310-5283-2018-11-16}

Мета. Метою даного дослідження є аналіз основних факторів, щуо впливають на екологічні параметри та показники безпечності будівельних матеріалів, а саме бетонних конструкцій, визначення механізмів їх оцінки та пошук напрямків захисту людини від впливу негативних елементів, щуо містяться у стінних будівельних матеріалах.

Методика. При дослідженнях використовували передбачені діючими державними стандартами методи, які дозволяють вивчити екологічні властивості будівельних матеріалів.

Результати. Досліджено екологічну безпечність матеріалів, які використовуються при зведенні будинків. Встановлено негативний вплив на здоров'я людини матеріалів, що містять понаднормову кількість природних радіонуклідів Запропоновано методи їх визначення, оцінки та зниження вмісту иляхом якісного та ретельного відбору наповнювачів та сировини.

Наукова новизна. Проаналізовано основні будівельні матеріали, з яких на даному етапі розвитку науки, проектуються будівельні конструкиії. Велика увага приділена бетону - як наймасовішому штучному матеріалу, який сьогодні виробляється на нашій планеті.

Практична значимість. Будівельні матеріали та конструкиї з них крім міцності, надійності та тріщиностійкості, повинні також відповідати екологічним вимогам та бути безпечними до подальшої експлуатації. Очінити з великою точністю матеріальні витрати, що виникають через використання екологічно-небезпечних та шкідливих будівельних матеріалів надзвичайно важко. Але варто відмітити, щу збереження екологічно-безпечного навколишнього середовища для майбутніх поколінь $\epsilon$ актуальною проблемою людства, яка з кожним десятиліттям стає все критичнішою.

Ключові слова: екологічна безпечність, природні радіонукліди, будівельні матеріали, будівельні конструкиії, бетон, якість, питома ефективна активність. 
Постановка проблеми у загальному вигляді $і$ їі зв'язок з важливими науковими та практичними завданнями. Відповідно до статті 3 Конституції України, людина, її життя і здоров'я, честь і гідність, недоторканість і безпека визнаються в Україні найвищою соціальною цінністю. Обов'язок держави захищати життя людини. Важливою ознакою якості життя $є$ захищеність людини від різних небезпек і загроз. Безпека для здоров'я означає можливість жити в екологічно не агресивному для здоров'я помешканні та довкіллі.

Повноцінне в гігієнічному відношенні житло повинно бути побудоване 3 безпечних матеріалів i конструкцій, достатньо просторим, сухим, мати сприятливий мікроклімат, чисте повітря, достатню інсоляцію - щоб у нього потрапляло пряме сонячне світло. У зв'язку 3 посиленням забруднення зовнішнього середовища та зі значним розширенням асортименту будівельних матеріалів за останні десятиліття зросли вимоги до санітарного стану житла.

Проблема екологічності місця існування досить нова, оскільки ще буквально 100-150 років тому людина харчувалась екологічно чистими продуктами, дихала чистим повітрям, жила в екологічно чистих будинках. Сьогодні ми піддаємося шумовим навантаженням, вдихаємо повітря 3 вихлопними газами, стикаємося 3 промисловою і побутовою радіацією, їмо їжу, вирощену на нітратах, піддаємося дії радіовипромінювання і високочастотних магнітних полів. Усі перераховані чинники оточують нас повсюдно. Досить сказати, що всесвітня організація охорони здоров'я стверджує, що повітря в міській квартирі забруднене в середньому в п'ять разів сильніше, ніж за їі межами. Тому зрозуміле прагнення людини знімати 3 себе стресове навантаження і періодично відпочивати від благ цивілізації.

Сьогодні ж постає питання підвищення стандартів якості життя шляхом забезпечення екологічної оптимізації архітектурно-будівельних, конструктивних i технологічних рішень 3 урахуванням унеможливлення негативних впливів на довкілля. При цьому особлива увага повинна бути приділена таким питанням, як якість та безпечність будівельних матеріалів.

Будівельна галузь України є однією з найважливіших галузей нашого народного господарства, від якої залежить ефективність функціонування всієї системи господарювання країни. Важливість цієї галузі для економіки будьякої країни можна пояснити таким чином: капітальне будівництво створює велику кількість робочих місць та використовує продукцію багатьох галузей народного господарства. Економічний ефект від розвитку цієї галузі полягає у мультиплікативному ефекті коштів, вкладених у будівництво. Адже 3 розвитком будівельної галузі розвиваються: виробництво будівельних 
матеріалів і відповідного обладнання, машинобудівна галузь, металургія та металообробка, нафтохімія, виробництво скла, деревообробна і фарфорофаянсова промисловість, транспорт, енергетика тощо. Також будівництво як жодна інша галузь економіки сприяє розвитку підприємств малого та середнього бізнесу.

Кількість будівельних і обробних матеріалів збільшилася в декілька разів. Кількість будівельних компаній вимірюється сотнями, кількість компаній тих, що поставляють матеріали - тисячами. При цьому постачальників в першу чергу цікавить прибуток, а будівельників - економія. Тому увесь асортимент будівельних матеріалів, вживаних в сучасному будівництві, можна розділити на:

- відносно безпечні;

- такі, які потребують строгого контролю.

Враховуючи вищезазначене, у зв'язку із розвитком нових технологій, екологічність людського житла повинна виноситись на перший план, прискіпливо розглядатись від початку проектування житла та до самої утилізації. Тому тема даного дослідження є досить актуальною.

Аналіз останніх досліджень, у яких започатковано вирімення проблеми. Досліджень в данійсфері проводилось доволі багато як іноземними так i вітчизняними науковцями. В Європі високу популярність має італійський журнал «l'informatoredelMarmista”, в якому досить розгорнуто розкриваються питання, пов'язані із перевагами будівельних матеріалів, їх безпечністю та екологічністю. Що стосується вітчизняної теоретичної бази, то сюди можна віднести таких науковців як Крисюк Е.М., Пархоменко В.І., Чеснаков О.В., в дослідах яких досить широко розкривається питання радіоактивності різноманітних матеріалів та норм радіаційної безпеки. Дослідники стверджували, що 75\% часу людина проводить у тих чи інших приміщеннях (вдома, на роботі, у навчальних закладах, магазинах, спортивно-розважальних закладах тощо), тому до числа чинників, що істотно вливають на ії здоров'я, відноситься ступінь екологічності (біопозитивності) середовища будівель, особливо житлових. Також дане питання у своїх працях висвітлювали такі науковці як: В.І. Борейко, І.М. Коломєць, Б.М. Литвин, М.Ю. Назукін, Л.І. Савчук та інші. Однак, сучасний стан та динаміка розвитку ринку будівельних матеріалів потребують виокремлення специфічних підходів до його аналізу і нових досліджень проблеми [1-3].

Цілі статmi. Метою даного дослідження є аналіз основних факторів, що впливають на екологічні параметри та показники безпечності будівельних 
матеріалів, а саме бетонних конструкцій, визначення механізмів їх оцінки та пошук напрямків зменшення їх негативного впливу та захисту людини від впливу негативних елементів, що містяться у стінних будівельних матеріалах.

Об’ккм досліджсення - будівельні конструкції, зокрема бетон та його складові.

Виклад основного матеріалу дослідження 3 повним обгрунтуванням отриманих наукових результатів. Виробники, прагнучи покращити властивості будівельної продукції, в процесі виготовлення практично завжди додають сировину, в якій містяться мікродомішки ізотопів урану, радію, торію, та калію. Як результат, бетон стає небезпечним для людини після того, як в нього додають присадки у вигляді форміату або нітриту натрію, які впливають на швидкість твердіння [4].

Пропонуємо більш детально розглянули питання екологічної безпеки на прикладі монолітно-каркасного методу будування. Перевагами даного методу $\epsilon$ довговічність близько (150 років), а також можливість легкого перепланування внутрішніх приміщень. Внаслідок великої сили зчеплення металу з бетоном обидва матеріали починають працювати як одне ціле. Це сприяє тому, що залізобетон стає одним із лідерів серед матеріалів будівельної галузі. Однак з точки зору екологічної безпечності даний матеріал має певні недоліки. Так він негативно впливає на мікрокліматичні параметри, зокрема має низьку повітря проникаючу здатність і низький коефіцієнт термоопору. У результаті чого порушується тепло вологий режим, який найбільше впливає на комфортні умови перебування людини в приміщенні. Великим недоліком цього матеріалу $є$ те, що металеві стрижні арматури екранують природне електромагнітне поле Землі, через що певні групи людей можуть відчувати дискомфорт. Одним із варіантів вирішення цієї проблеми $\epsilon$ армування залізобетонних конструкцій не масивними сталевими стрижнями (арматурою), а дисперсно розташованими сталевими фібрами довжиною 30..50 мм. Магнітне поле, що виникає в дисперсно армованих конструкціях буде в рази слабшим, ніж у типових залізобетонних. Проектування інженерних конструкцій з дисперсним армуванням бетону (сталефібробетон) iз врахуванням їх екологічності описані в роботах [5-9].

Існуюча на сьогодні система контролю якості будівельних матеріалів потребує суттєвого доопрацювання та вдосконалення. В сучасних умовах одним із домінуючих факторів при виборі будівельних матеріалів $\epsilon$ їх безпечність.

На рис.1 наведено класифікацію екологічних властивостей матеріалу. 


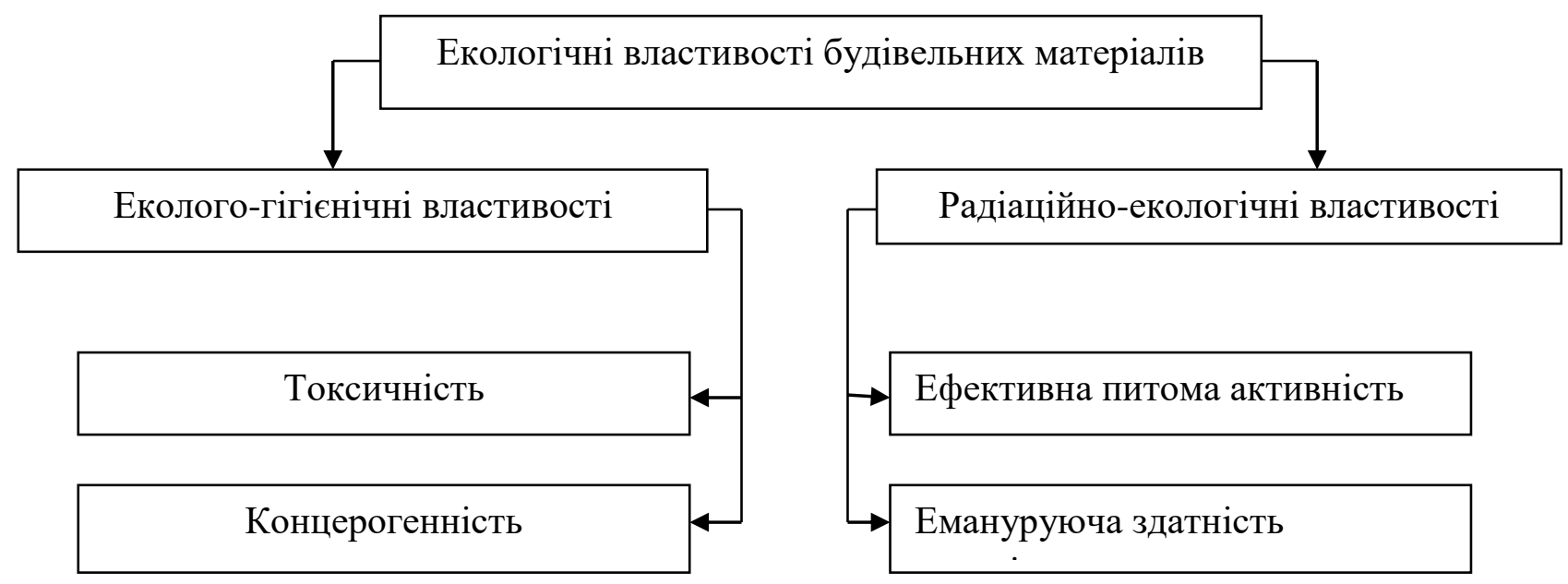

\section{Рис.1. Екологічні властивості будівельних матеріалів}

3 екологічної точки зору, будівельні матеріали характеризуються радіаційно-екологічними та еколого-гігієнічними показниками. Як ми бачимо 3 рисунку, радіаційно-екологічні властивості поділяються на ефективну питому активність ПРН та емануруючу здатність матеріалу, а екологогігієнічні властивості поділяються за рівнем токсичності та рівнем концерогенності.

Дослідження показують, що на здоров'я людини великий вплив мають будівельні матеріали, які у своєму складі містять природні радіонукліди. Природні радіонукліди (ПРН) - це основні радіоактивні нукліди природного походження, що містяться в будівельних матеріалах. До них відносяться радій (226 Ra), торій (232 Th) та калій (40 K) згідно ГОСТ 30108-94.

Із введенням в дію ГОСТ 30108-94 «Матеріали і вироби будівельні. Визначення питомої ефективної активності природних радіонуклідів» обов'язковою процедурою стало дослідження зразків будівельних матеріалів на питому ефективну активність природних радіонуклідів ЯРадія-226, Торія232 і Калія-40. Критерієм оцінки є питома ефективна активність (Аеф), по значенню якої встановлюється належність матеріалу до 1, 2 або 3 класу і визначається можлива галузь його застосування. В подальшому ці характеристики використовуються у сертифікатах.

Ефективна питома активність природних радіонуклідів (Аеф) не повинна перевищувати встановленої норми. Встановлені такі допустимі числові значення (класи) Аеф природних радіонуклідів в будівельних матеріалах:

1) Аеф < 370 Бк/кг (1 клас) - будівельний матеріал може використовуватисядля усіх видів будівництва без обмежень; 
2) Аеф< 740 Бк/кг (2 клас) - будівельний матеріал може використовуватися для дорожнього та промислового будівництва (час перебування людей повинен бути меншим, ніж 1700 год/рік);

3) Аеф< 1350 Бк/кг (3 клас) - будівельний матеріал може використовуватися для таких об'єктів:

- промислового призначення, практично не пов'язаних 3 перебуванням людей;

- дорожнього призначення поза населеними пунктами;

- дорожнього призначення в межах населених пунктів за умови покриття шаром грунту або іншого матеріалу товщиною не менше, ніж 0,5 м.

Для використання будівельних матеріалів 3 Аеф> 1350 Бк/кг у всіх випадках необхідно одержати дозвіл Державного санітарного нагляду. Згідно 3 НРБУ-97, величина Аеф не повинна перевищувати 3700 Бк/кг для матеріалів, що мають естетичну цінність. Якщо цей показник перевищує попередньо зазначені норми, то будівельний матеріал повинен бути визнаний браком та не застосовуватись.

Типові документи по проведенню радіаційного контролю сировини, будівельних матеріалів та об'єктів будівництва містяться в ДЕН В. 1.4-0.02-97. Система норм та правил зниження рівня іонізуючих випромінювань природних радіонуклідів в будівництві.

У складі бетону є досить багато наповнювачів, які містять у своєму складі природні радіонукліди, тому в процесі виготовлення даного матеріалу досить важливим $\epsilon$ процес планування та прогнозування, щоб на кінцевому етапі отримати допустиму норму радію, торію та калію. Тому надзвичайно важливо використовувати екологічні безпечні матеріали для виготовлення бетонів (пісок, щебінь, цемент, вапно, керамзит, пластифікатори, протиморозні та хімічно активні добавки, і т.д.).

Одним із найбільш радіаційно небезпечним компонентом бетону є щебінь - неорганічний зернистий великоуламковий сипучий матеріал, що добувається методом дроблення гірських порід, а також паралельно добутих розкривних і вмісних порід або некондиційних відходів гірських підприємств по переробці руд, та складається з майже необкатаних гострокутних зерна твердих порід розміром 10-100 мм. Від скельної природньої породи, з якої вироблений щебінь (базальт, граніт, мігматит, гранодіорит, андезит, габро, кристалічний сланець, кварцит і т.д.) буде залежати й рівень його радіаційного фону. Також варто відмітити, що в щебні можуть бути присутні шкідливі домішок - включення піриту, марказиту, піротину і інших сульфідів; гіпсу, 
ангідриту і інших сульфатів; магнетиту, гематиту, гетиту і інших окислів i гідроокисів заліза; опалу, халцедону, кремнію, слюди і гідрослюд; хлоритів; галіту, сильвіну i інших галогенних сполук; сірки, азбесту, апатиту, фосфориту, графіту, вугіллю, горючих сланців, ав сировині для баластного каменю, крім цих, шкідливими є струмопровідні домішки.

На сучасному етапі розвитку науки та техніки під час проведення прикладних лабораторних досліджень будівельних матеріалів особлива увага приділяється комп'ютерному моделюванню, i в т.ч. під час досліджень залізобетонних і сталефібробетонних конструкцій [10-12]. За допомогою прикладних програм можна змоделювати їх склад та майбутні механічні характеристики бетонної суміші з заданими властивостями, і в т.ч. сумарний екологічно-негативний вплив і радіаційний фон готової суміші (за основу приймаються в розрахунку складові компоненти та враховуються умови експлуатації конструкцій).

Слід зазначити, що при виборі будівельних матеріалів із підвищеним фоном радіації, радіаційний фон підвищується і в будинку. Тому важливо підраховувати сумарний рівень радіаційного фону від усіх можливих джерел і не допускати, щоб сума навантажень перевищила показник природного фону. Інформацію для подібних розрахунків необхідно брати із нормативних документів, підкріплених до даних матеріалів. Сьогодні для такої оцінки використовують радієвий еквівалент. В табл.1 наведено радієвий еквівалент для ізотопів:K, Ra, Th для найбільш поширених будівельних матеріалів

Таблиця 1

Радісвий еквівалент широко застосовуваних будівельних матеріалів

\begin{tabular}{|l|c|}
\hline \multicolumn{1}{|c|}{ Матеріал } & Радієвий еквівалент пКі/г \\
\hline Будівельний камінь & $0,9-15,9$ \\
\hline Бетон & $0,5-10,1$ \\
\hline Цегла глиняна (червона) & $2,2-7,0$ \\
\hline Цемент & $0,8-4,3$ \\
\hline Щебінь & $0,1-3,2$ \\
\hline Вапно & $0,1-2,6$ \\
\hline Пісок & $0,9-11,6$ \\
\hline
\end{tabular}

Згідно таблиці, найменший радієвий еквівалент містить вапно, а найбільший - будівельний камінь та пісок, тому саме на ці матеріали потрібно звертати особливу увагу на етапі проектування майбутньої будівлі.

В СС досить гостро стоїть питання екологічної безпечності будівельних матеріалів. У них немає норм, які б регулювали вміст природних 
радіонуклідів, проте вони регламентують вміст радону в приміщеннях (результат розпаду радіонуклідів), згідно 3 якими для об'єктів нового

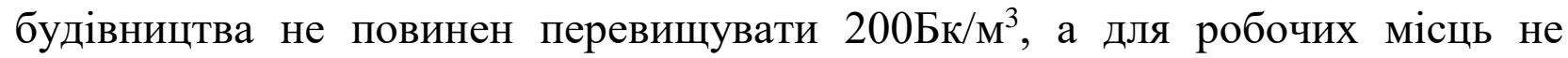
повинен бути більше 500 Бк/м³.

Висновки та перспективи подальших досліджень. Для вирішення завдання із захисту людини від негативного впливу будь-якого джерела іонізуючого опромінення (ДІО) необхідно встановити фізичну природу його параметрів. Ми дослідили:

- властивості домінуючих природних радіонуклідів в будівельних матеріалах, що $\epsilon$ необхідним для управління радіаційними параметрами штучних будівельних матеріалів і перш за все, всього бетону.

- механізм формування радіаційного фону штучних будівельних матеріалів в залежності від їх складу, технології виготовлення і наступної експлуатації будівель.

Результати показали, що на сьогоднішній день в Україні не достатньо уваги приділяється такому питанню, як оцінка безпечності будівельних матеріалів і в т.ч. бетонів та його складових компонентів. Номенклатура даної продукції $\epsilon$ досить широкою і постійно зростає. Вміст деякої із них не відповідає встановленим «Нормам радіаційної безпеки» (НРБ-99) та вимогам ГОСТ 30108-94 «Матеріали і вироби будівельні. Визначення питомої ефективної активності природних радіонуклідів». У подальших дослідженнях розглянемо шляхи вдосконалення екологічних властивостей будівельних матеріалів.

\section{Література}

1. Борейко В. І. Перспективи виробництва будівельних матеріалів в Україні / В.І. Борейко, М.Ю. Притула // Збірник наукових праць. Проблеми раціонального використання соціально-економічного та природно-ресурсного потенціалу регіону: фінансова політика та інвестиції. - 2011. - Випуск XVII, № 4. - С. 64-71.

2. Забезпечення промислової та цивільної безпеки в Україні та світі: управління, технології, моделі: колективна монографія / Андрійчук О.В., Андрощук I.В., Бондарчук Л.Ф. та ін., за наук. ред. проф. Матвійчук Л.Ю. - Луцьк: РВВ Луцького НТУ, 2016. -220 с.

3. ШутенкоЛ.М.Міський житловий фонд: життєвий цикл і радіаційна безпека/ Л.М.Шутенко. - К.: Техніка, 2002. - 251с.

4. Ткачук В.В. Товарознавча оцінка екологічних показників будівельних матеріалів / В.В. Ткачук, Д. В. Дзюбинський // Екологічні нотатки. - № 3. - Луцьк: РВВ Луцький НТУ. 2016 - С. 53-58.

5. Бабич Є.М. Про доцільність використання сталефібробетону для виготовлення безнапір-них труб / Є.М. Бабич, О.В. Андрійчук // Ресурсоекономні матеріали, конструкції, будівлі та споруди: Збірник наукових праць - Рівне: НУВГП, 2009. - Випуск 18. - С. 119 126. 
6. Бабич Є.М. Проектування та виготовлення безнапірних труб із сталефібробетону / Є.М. Бабич, О.В. Андрійчук // Рекомендації. - Луцьк: ЛНТУ, 2012. - С. 32.

7. Андрійчук О.В. Сталефібробетонні безнапірні труби / О.В. Андрійчук, Є.М. Бабич // Монографія. - Луцьк: РВВ Луцького НТУ, 2012. - 150 с.

8. Андрійчук О.В. Виготовлення придорожніх лотків водовідводу зі сталефібробетону / О.В. Андрійчук, I.М. Ясюк// Наукові нотатки: збірник наукових праць - Луцьк: Луцький НТУ, 2014. - Випуск 45. - С. 7 - 14.

9. Андрійчук О.В. Сталефібробетонні лотки водовідведення / О.В. Андрійчук, I.M. Ясюк // Монографія. - Луцьк: РВВ Луцького НТУ, 2018. - 150 с.

10. Babych E.M. Strength of Elements with Annular Cross Sections Madeof Steel-fiberReinforced Concrete Under One-Time Loads/ O.V.Andriichuk, E.M. Babych // Materials Science, Vol. 52, No. 4, New York - 2017, p. 509 - 513.

11. Городецкий А.С., Компьютерное моделирование в задачах строительной механики / А.С. Городецкий, М.С. Барабаш, В.Н. Сидоров // Учебное пособие. Издательство АСВ. - 2016. - с. 338.

12. Григорчук А.Б. Оцінка напружено-деформованого стану згинальних залізобетонних елементів при дії малоциклового знакозмінного навантаження 3 використанням ПК «Ліра» // Ресурсоекономні матеріали, конструкції, будівлі та споруди: Збірник наукових праць - Рівне: НУВГП, 2011. - Випуск 22. - С. 272 - 277.

Цель. Целью данного исследования является анализ основных факторов, влияющих на экологические параметры и показатели безопасности строительных материалов, а именно бетонных конструкций, определения механизмов их оценки и поиск направлений защиты человека от влияния негативных элементов, содержащихся в стеновых строительных материалах.

Методика. При исследованиях использовали предусмотренные действующими государственными стандартами методы, которые позволяют изучить экологические свойства строительных материалов.

Результаты. Исследовано экологическую безопасность материалов, используемых при возведении зданий. Установлено негативное влияние на здоровье человека материалов, содержащих сверхурочную количество природных радионуклидов Предложены методы их определения, оценки и снижения содержания путем качественного и тщательного отбора наполнителей и сырья.

Научная новизна. Проанализированы основные строительные материаль, из которых на данном этапе развития науки, проектируются строительные конструкиии. Большое внимание уделено бетона - как массовом искусственном материала, который сегодня производится на нашей планете.

Практическая значимость. Строчтельные материальы и конструкиии из них кроме прочности, надежности и трещиностойкости, должны также соответствовать экологическим требованиям и быть безопасными к дальнейтей эксплуатаџии. Оценить с большой точностью материальнье затраты, возникающие из использования экологически опасных и вредных строительных материалов чрезвычайно трудно. Но стоит отметить, что сохранение экологически безопасной окружающей среды для будущих поколений является актуальной проблемой человечества, которая с каждым десятилетием становится все более критической.

Ключевые слова: экологическая безопасность, природные радионуклиды, строительныле материаль, строчтельныле конструкции, бетон, качество, удельная эффективная активность. 
Goal. The purpose of this study is to analyze the main factors influencing the environmental parameters and indicators of safety of building materials, namely, concrete structures, determination of mechanisms for their evaluation and the search for directions of human protection from the influence of negative elements contained in wall building materials.

Method. In researches used methods provided by the acting state standards that allow to study the environmental properties of building materials.

Results. The ecological safety of the materials used in the construction of houses is investigated. The negative influence on human health of materials containing excessive amount of natural radionuclides has been established. The methods of their determination, estimation and reduction of content by qualitative and thorough selection of fillers and raw materials are offered.

Scientific novelty. The basic building materials are analyzed, from which at this stage of development of science, building constructions are projected. Much attention is paid to concrete as the most massive artificial material that is produced today on our planet.

Practical significance. Building materials and structures, in addition to strength, reliability and cracksmanship, must also comply with environmental requirements and be safe before further exploitation. It is extremely difficult to estimate with material accuracy the material costs arising from the use of environmentally hazardous and harmful construction materials. But it should be noted that the preservation of an environmentally safe environment for future generations is an urgent problem of humanity, which becomes more critical every decade.

Key words: ecological safety, natural radionuclides, building materials, building structures, concrete, quality, specific effective activity.

Рекомендовано до публікаиії докт.техн.наук, професором Луиького НТУ Байдаковою Л.І. Дата надходження в редакиію 22.01.2018 р. 